\title{
Recent Progress for the Utilization of Curcuma longa, Piper nigrum and Phoenix dactylifera Seeds against Type 2 Diabetes
}

\author{
T Khaliq ${ }^{1}$, M Sarfraz $^{1}$, MA Ashraf $^{2,3}$
}

\begin{abstract}
Background: Diabetes mellitus is an important human disease afflicting many from various walks of life in different countries. Even though modern medicines contribute a variety of effective treatment options, they can have several unfavourable effects. The intention of this review is to organize and discuss various studies that have been previously conducted on the effectiveness of these herbal plants in diabetes. Method: By using various electronic search databases, a comprehensive English literature search was conducted. Different search terms were used by combining all the search fields in titles, abstracts and keywords.

Results: Curcuma longa, a spice, is commonly known as turmeric and belongs to the family Zingiberaceae. Piper nigrum is also a spice, commonly called black pepper, and belongs to the family Piperaceae. Phoenix dactylifera, commonly known as date fruit, belongs to the family Arecaceae. From ancient times, they have been traditionally used for the treatment of various diseases. Among various activities, regulation of hyperglycaemia is considered one of their important effects. One of the aetiological factors implicated in the development of diabetes and its complications is the damage induced by free radicals. Antioxidant properties of antidiabetic compounds would be more beneficial. Extracts of these plants have shown hypoglycaemic and hypolipidaemic effects by the involvement of several mechanisms. In the future, further studies are needed to investigate the mechanisms involved in their hypoglycaemic potential and their active constituents as synthetic analogues.

Conclusions: This review focusses on some medicinal plants that have antidiabetic effect, thus contributing to the reduction of risk factors associated with diabetes, and related beneficial effects are compiled.
\end{abstract}

Keywords: Black pepper, date seed, diabetes, turmeric

\section{Avances Recientes en la Utilización de las Semillas de Curcuma longa, Piper nigrum and Phoenix dactylifera contra la Diabetes Tipo 2}

T Khaliq ${ }^{1}$, M Sarfraz ${ }^{1}$, MA Ashraf $^{2,3}$

\begin{abstract}
RESUMEN
Antecedentes: La diabetes mellitus es una enfermedad importante que afecta a muchos seres humanos en distintos ámbitos de la vida en diferentes países. Aunque los medicamentos modernos aportan una variedad de opciones para un tratamiento efectivo, los mismos tienen varios efectos desfavorables. La intención de este estudio es organizar y revisar diversos estudios que se han realizado anteriormente sobre la efectividad de estas plantas herbales en la diabetes.

Método: Mediante el uso de varias bases de datos de búsqueda electrónica, se realizó una búsqueda
\end{abstract}

From: ${ }^{1}$ Institute of Pharmacy, Physiology and Pharmacology, University of Agriculture, Faisalabad 38040, Pakistan, ${ }^{2}$ Faculty of Science and Natural Resources, Universiti Malaysia Sabah, 88400 Kota Kinabalu, Sabah, Malaysia and ${ }^{3}$ Department of Environmental Science and Engineering, School of Environmental Studies, China University of Geosciences, Wuhan 430074, PR China.
Correspondence: Dr M Sarfraz, Institute of Pharmacy, Physiology and Pharmacology, University of Agriculture, Faisalabad 38040, Pakistan. E-mail: maliha.sarfraz@uaf.edu.pk 
amplia de la literatura inglés. Se utilizaron términos de búsqueda combinando todos los campos de búsqueda en títulos, resúmenes y palabras claves.

Resultados: Curcuma longa, una especia, es comúnmente conocida como cúrcuma, y pertenece a la familia Zingiberaceae. Piper nigrum, también una especia, comúnmente se conoce como pimienta negra, y pertenece a la familia Piperaceae. Finalmente, Phoenix dactylifera, comúnmente conocida como palma datilera, pertenece a la familia Arecaceae. Desde la antigüedad, estas plantas se han utilizado tradicionalmente para el tratamiento de diversas enfermedades. Entre sus usos diversos, la regulación del potencial hiperglicémico es considerado uno de los efectos importantes. Uno de los factores etiológicos implicados en el desarrollo de la diabetes y sus complicaciones es el daño inducido por radicales libres. Las propiedades antioxidantes de los compuestos antidiabéticos serían más beneficiosas. Los extractos de estas plantas han mostrado poseer efectos hipoglicémicos e hipolipidémicos por medio de la participación de varios mecanismos. En el futuro, más estudios son necesarios para investigar los mecanismos implicados en su potencial hipoglicémico y sus componentes activos como análogos sintéticos.

Conclusiones: Esta revisión se centra en algunas plantas medicinales que tienen efectos antidiabéticos, contribuyendo así a la reducción de factores de riesgo asociados con la diabetes. Asimismo, se compilan efectos beneficiosos relacionados.

Palabras claves: Pimienta negra, semilla de dátil, diabetes, cúrcuma

West Indian Med J 2015; 64 (5): 528

\section{INTRODUCTION}

Diabetes mellitus (DM) is one of the oldest diseases known to man. It was first reported in Egyptian manuscripts about 3000 years ago (1). It is a clinical syndrome. Distinction between Type 1 and Type 2 DM was made in 1936. Type 1 diabetes (insulin dependent) is characterized by deficient insulin production while Type 2 diabetes (non insulin-dependent) is the most common form and is characterized by inappropriate hyperglycaemia due to deficiency of or resistance to insulin. Absolute or relative lack of insulin affects the metabolism of fat, protein, carbohydrate, water and electrolytes. The recommendations of the World Health Organization on the use of alternative medicines for treating diabetes provide an impetus for research in this area (2).

The centre of attention of research in diabetes includes discovering newer antidiabetic agents and isolating the active compounds from herbal sources that have been recognized to have antidiabetic properties as have been described in ancient texts. A single herb has different actions on many diseases but each herb may have one dominating effect and other comparatively subsidiary effects. Each herbal drug can also have synergistic and antagonist effects in combination with other herbs (3). Plant materials which are being used as traditional medicine for the treatment of diabetes are considered one of the good sources for a new drug or a lead to make a new drug. Plant extracts or different folk plant preparations are being prescribed by the traditional practitioners and also accepted by the users for diabetes like for any other disease in many countries. The current review focusses on some herbal plants used in the treatment of diabetes which is a major worldwide disease.

\section{METHOD}

A comprehensive online search of the English literature was conducted via electronic databases including MEDLINE, Em- base, PubMed and Scopus. Different search terms were used such as Curcuma longa, Piper nigrum, Phoenix dactylifera, date seed, antihyperglycaemic agents, hypolipidaemic effect, Type 2 diabetes, and antioxidants. Appropriate articles were selected after using these terms. Finally, all the selected articles were confirmed for duplication.

\section{RESULTS}

\section{Diabetes mellitus}

According to the World Health Organization, diabetes is a chronic disease that occurs when the pancreas does not produce enough insulin or when the body cannot efficiently use the insulin it produces. It has emerged as an epidemic all over the world (4). If it is not properly managed, it can lead to lifethreatening problems and premature deaths. Incidence of diabetes is $170 \%$ in developing countries as compared to $47 \%$ in developed countries. There are 366 million people affected with diabetes mellitus globally (5) and the number of people affected is expected to rise to 552 million worldwide. The International Diabetes Federation estimates that there are 6.7 million people living with diabetes in Pakistan and this number will rise to 12.8 million people by 2035 . Some local studies have shown that, in children, risk for developing diabetes is high, not due to family history, but due to their lifestyle (6).

In the allopathic system of medicine, the oral hypoglycaemic drugs used for Type 2 diabetes are sulfonylureas (tolbutamide, glibenclamide, chlorpropamide, glipizide, acetohexamide, gliclazide and tolazamide) and biguanides (phenformin and metformin). Some new drugs for Type 2 diabetes include glitazone (decrease insulin resistance by interaction with peroxisome proliferator-activated receptor involved in lipid metabolism) and repaglinides (stimulate insulin production at meal times). Sitagliptin, saxagliptin and vildagliptin (dipeptidyl peptidase- 4 inhibitors) are effective in the treatment of 
Type 2 diabetes (7). In the late 1990s, glitazones were used in the treatment of diabetes. These synthetic hypoglycaemic drugs cause serious side effects: sulphonylureas cause skin rash, impaired renal and hepatic dysfunction; thiazolidinediones cause weight gain, oedema and increased risk of bladder cancer; biguanides/metformin cause sickness with alcohol, kidney complications, upset stomach, tiredness or dizziness and a metallic taste; $\alpha$-glucosidase inhibitors cause abdominal bloating, flatulence and diarrhoea (8). These associated problems require the search for better drugs derived from plants with fewer side effects. According to ethnobotanical information, about 800 plants possess antihyperglycaemic effect. On the other hand, few reports are accessible on the hypoglycaemic potential of combination of different herbal plants. Different herbal remedies, when used in combination, are more effective because their bioactive phytoconstituents impart synergic therapeutic potential and help the body to control possible adverse effects. Thus, it is better to use herbal combination instead of a single herb (9).

In plants, several phytoconstituents, with different modes of action, have antidiabetic potential. There are some phytoconstituents with specific modes of action that decrease plasma glucose level. Pan et al reported that alkaloids inhibit $\alpha$-glucosidase and reduce the glucose transport to the intestinal epithelium (10). Imidazoline compounds stimulate insulin secretion, polysaccharides increase serum insulin level, flavonoids increase hepatic glucokinase activity, perhaps by enhancing insulin release from pancreatic islets, and significantly reduce the level of glucose, triglycerides and cholesterol, dietary fibres inhibit $\alpha$-amylase activity and effectively absorb glucose and retard glucose diffusion (11). Ng et al documented that saponins - triterpenoid and steroidal glycoside stimulate the release of insulin and blocks the formation of glucose in the blood stream (12). Experimental evidence reveals the involvement of free radicals in the pathogenesis and complications of diabetes. These radicals are able to damage cell proteins, lipids and DNA which alter the cell function. Antioxidants neutralize free radicals and are effective in preventing experimentally induced diabetes in animal models (13). In diabetic patients, free radicals target the extracellular protein and, due to hyperglycaemia, modify them to glycoproteins. These modifications are associated with the development of diabetic complications. During diabetes, very low density lipoprotein (VLDL), low density lipoprotein (LDL), and high density lipoprotein (HDL) are produced due to oxidation of lipoproteins by free radicals. Oxidative stress in diabetic conditions enhances lipid peroxidation (14).

\section{Curcuma longa (turmeric)}

Turmeric (Curcuma longa), belonging to the family Zingiberaceae, is extensively cultivated in China and India. The taxonomic classification is shown in Table 1 . It is valued due to its yellow colour and flavour. It is used for making curry powders in large quantities. Traditionally, rhizome of turmeric has been
Table 1: Taxonomic classification

\begin{tabular}{|c|c|c|c|}
\hline Kingdom & $\begin{array}{l}\text { Turmeric } \\
\text { plantae }\end{array}$ & $\begin{array}{l}\text { Black pepper } \\
\text { plantae }\end{array}$ & $\begin{array}{l}\text { Ajwa date } \\
\text { plantae }\end{array}$ \\
\hline Division & Tracheophyta & Manoliophyta & Magnoliophyta \\
\hline Class & Magnoliopsida & Magnoliopsida & Liliopsida \\
\hline Order & Zingiberales & Piperales & Arecales \\
\hline Family & Zingiberaceae & Piperaceae & Arecaceae \\
\hline Genus & Curcuma & Piper & Phoenix \\
\hline Species & C longa & P nigrum & $P$ dactylifera \\
\hline
\end{tabular}

used in the form of expressed juice along with the fruit of Emblica officinalis (amla) for treating diabetes (15).

Curcumin (structure shown in Table 2), an active ingredient isolated from C longa, has been shown to have hypoglycaemic, antioxidant and lipid lowering effects in experimental studies. Srinivisan and Sambaiah reported that curcumin has blood sugar lowering effect in diabetic individuals, but in that study only one diabetic patient was included (16).

Table 2: Recognized active principles and medicinal properties of spices

\begin{tabular}{llll}
\hline Spice & $\begin{array}{l}\text { Active } \\
\text { principle }\end{array}$ & Chemical structure & Medicinal properties \\
\hline Turmeric & Curcumin & $\begin{array}{l}\text { Antibacterial, anti-inflamma- } \\
\text { tory, diuretic, laxative; good } \\
\text { for affections of the liver, } \\
\text { jaundice, diseases of blood; } \\
\text { anticancer } \\
\text { Black pepper }\end{array}$ & Piperine
\end{tabular}

After that discovery, curcumin was used in various rodent models to investigate its hypoglycaemic activity. Different doses of curcumin for different days have been used to check its effects. Diabetes has been induced by alloxan and streptozotocin. Oral administration of various dosage of curcumin is used to control diabetes. In different studies, curcumin $80 \mathrm{mg} / \mathrm{kg}$ bodyweight for 21 days (17) and for 45 days were administered orally; they decreased blood glucose level, thiobarbituric acid reactive substance (TBRAS), oxidative stress and improved insulin sensitivity in hyperglycaemic rats, respectively (18). Arun and Nalini hypothesized that it may be due to decreased influx of glucose in the polyol pathway, in this manner increasing NADPH/NADP ratio and improving the activity of glucose peroxidase enzyme (17).

According to Nishiyama et al, ethanolic extract of turmeric was more strongly hypoglycaemic and they suggested that turmeric component exhibited synergistic effects (19). The oral dose of curcumin $60 \mathrm{mg} / \mathrm{kg}$ body weight for 14 days (20) and $90 \mathrm{mg} / \mathrm{kg}$ body weight for 15 days in hyperglycaemic rats were studied and they showed antidiabetic activity (21). In another study which was conducted in 2011, a dose of 150 $\mathrm{mg} / \mathrm{kg}$ body weight for 49 days in hyperglycaemic rats prevented body weight loss and decreased blood glucose level (22). Different doses of curcumin for different days were used 
and they reduced the glucose level in diabetic rats for 56 days at $300 \mathrm{mg}$ (23) and $100 \mathrm{mg}$ for 30 days (24), seven weeks (25) and eight weeks (24).

El-Moselhy et al, in their study, described that an oral dose of $80 \mathrm{mg}$ of curcumin, given for 60 and 15 days to rats with induced Type 2 diabetes and high fat diet insulin resistance, had antidiabetic activity (26), while another study conducted in 2012 reported that dietary curcumin was effective in controlling the increased levels of fasting blood glucose (27).

The useful effect of curcumin has been suggested in diabetic dyslipidaemia, without varying the hyperglycaemic status in diabetic rats. A significant decline was indicated in blood cholesterol in curcumin-fed hyperglycaemic rats and this decrease was fully from LDL and VLDL fraction. It was also observed that serum triglycerides and phospholipids level were reduced significantly (28). Curcumin also has an antioxidant property. In rat liver microsomes, it inhibits lipid peroxidation significantly. It also reduces the improved accumulation of advanced glycation end products (AGEs) and cross-linking of collagen in tail tendon and skin of hyperglycaemic animals, thereby preventing AGE-induced complications of diabetes. Curcumin improved wound repair in diabetic animals and could be developed as a pharmacologic agent in diabetic ulcers (29). In diabetic nephropathy, excretion of larger amounts of higher molecular weight proteins and renal tubular enzymes takes place. It was observed that the hyperglycaemic animals fed on a curcumin diet reduced excretion of these proteins and urinary enzymes significantly than control diet fed rats (26). In different studies, it was indicated that curcumin and turmeric delayed cataract in rats in streptozotocin-induced hyperglycaemia (28).

\section{Piper nigrum (black pepper)}

Black pepper (Piper nigrum) belongs to the family Piperaceae and is a perennial plant producing berry-like and pungent fruit. Its active ingredient is piperine, structure shown in Table 2. It is cultivated in many tropical regions but it still occurs wild in the mountains of Kerala state in India. It has more than 1000 species and is a widely used spice. It is valued for its distinct biting quality attributed to piperine and its isomers (30).

Piperine has a hypoglycaemic effect in normal mice (31). Oral administration of Piper longum dried fruits has shown significant anti-hyperglycaemic, antioxidant and antilipid peroxidative effects in hyperglycaemic rats (32). In another study, Atal et al reported that piperine affects blood glucose level in alloxan-induced diabetic mice in acute and subacute study models. In the acute study, oral administrations of piperine were 10,20 and $40 \mathrm{mg} / \mathrm{kg}$ body weight and resulted in a rise in blood glucose level at high dose, while in the subacute study, piperine was administered at 5,10 and $20 \mathrm{mg} / \mathrm{kg}$ body weight and significantly decreased the glucose level (33). There were no significant changes in serum free and total cholesterol and liver total cholesterol in rats fed a normal diet supplemented with $0.02 \%, 0.15 \%, 0.5 \%, 2.0 \%$, and $5 \%$ pepper or $0.05 \%$ piperine or pepper oleoresin at $11 \%, 22 \%$ and $44 \%$ levels in the diet (34) for seven to eight weeks. In contrast, Cho and Lee reported that adding black pepper at $5 \%$ level in the diet of rats for eight weeks led to a significant increase in serum cholesterol. Dietary black pepper did not affect serum and liver cholesterol concentration and hepatic cholesterol-7a-hydroxylase, the rate-limiting enzyme in the conversion of cholesterol to bile acids (35).

The link between free radical formation and complication of diabetes has been well established. Phenolics effectively prevent diabetes in animal models. Black pepper oil has radical scavenging and ferric reducing antioxidant abilities (36). Oxidative stress is the major contributor of diabetes and piperine has antioxidant potential as documented in different studies. Vijayakumar et al reported in their study that intake of black pepper affects membrane lipid peroxidation, enzymatic and nonenzymatic antioxidants as well as oxidative stress in rats (37). Treatment with $P$ nigrum and $V$ rosea once a day for four weeks in alloxan-induced diabetic rats effectively controls the blood glucose level as well as affects lipid level and antioxidant potential. Piper nigrum has more antioxidant potential as compared to Piper longum and Zingiber officinale. Serum lipid levels prominently increase during diabetes, due to insulin resistance and altered metabolic mechanism which is responsible for lipid accumulation. Nabi et al reported that aqueous extract of Piper longum roots at a dose of $200 \mathrm{mg} / \mathrm{kg}$ significantly reduced the level of glucose, triglycerides, total cholesterol, LDL-C, VLDL-C and serum enzymes (38).

\section{Phoenix dactylifera (date fruit)}

Date fruit (Phoenix dactylifera) as a source of nutrition and because it is economical, has become important in some countries. Phoenix dactylifera is a monocotyledonous fruit tree that belongs to the Arecaceae family. World production of dates reached seven million tons in 2010; from this, around one million tons of date seeds are produced during this year [Table 3] (39).

Table 3: Top ten date producers, 2012 (1000 metric tonnes)

\begin{tabular}{|c|c|c|c|c|c|}
\hline $\bar{E}$ & Egypt & 1470 & c & Pakistan & 600 \\
\hline 플 & Iran & 1066 & w & Oman & 270 \\
\hline 몰 & Saudi Arabia & 1050 & E & United Arab Emirates & 250 \\
\hline 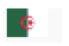 & Algeria & 789 & Q & Tunisia & 190 \\
\hline In & Iraq & 650 & a & Libya & 170 \\
\hline
\end{tabular}

Date seeds are considered as a waste product. In the date fruit, $11-18 \%$ of its weight comes from the seed. It is used in animal feeds or ground into smaller size and roasted to become a caffeine-free coffee substitute, used by the Arabs, whether plain or mixed with coffee. Date seed contains a significant amount of bioactive phenolics and dietary fibres (40). In order to determine the functional properties of date seed, various studies have been carried out such as dietary treatment, phenolic acid composition and protein solubility. These studies 
show that date seeds can be a good source of dietary fibre, phenolic components and natural antioxidants.

El-Fouhil et al reported that oral administration of date seed extract combined with insulin has an antihyperglycaemic effect as compared to seed extract alone in streptozotocin-induced diabetic rats (41). Date seed extract has the ability to protect against hepatotoxicity in rats. In another study, it was reported that date seed extract-insulin combination minimizes the toxic effects of diabetes on the liver and kidney of diabetic rats (42). A dose of $10 \mathrm{~mL}$ date seed extract in combination with insulin causes an increase in endogenous insulin secretion in streptozotocin diabetic rats which might be the cause of its hypoglycaemic effect (43). Halaby et al published in their study that oral administration of date pit fortified bread at $10 \%$ and $15 \%$ given to diabetic rats for 45 days results in a significant reduction in blood glucose level and improved serum lipid fraction as compared to the alloxanized control group (44).

\section{CONCLUSION}

In conclusion, turmeric, black pepper and date seed decrease blood glucose level and have some useful effects on the complications of diabetes. There is a need to evaluate the pharmacological actions of these compounds involving humans to justify the use of active principles of these plants as hypoglycaemic agents. More laboratory work is needed to isolate the active compounds, their actions and toxicity for the treatment of diabetes, as oral hypoglycaemic agents having hypolipidaemic and antioxidant potential.

In the future, we will study the effect of ajwa (date) seed powder, turmeric and black pepper as hypoglycaemic agents in diabetic rats by comparing the histopathological and immunocytochemical parameters; we will compare and identify the changes and determine biomarkers of health status in diabetic rats. The expected outcome is that the combination of turmeric, black pepper and ajwa seed powder possesses significant antihyperglycaemic, antihyperlipidaemic activity in diabetic rats and might prevent hyperglycaemic-associated risk factors.

\section{AUTHORS' NOTE}

The authors certify that there is no conflict of interest with any financial organization regarding the material discussed in the paper. TK carried out the design and coordinated the study; MS and MAA participated in most of the experiments and prepared the manuscript and also provide assistance in the design of the study. All authors have read and approved the content of the manuscript.

\section{REFERENCES}

1. Ahmed AM. History of diabetes mellitus. J Saudi Med J 2002; 23: $373-$ 8.

2. World Health Organization. Definition, diagnosis and classification of diabetes mellitus and its complications. Part 1: diagnosis and classification of diabetes mellitus. Geneva; WHO: 1999.
3. Umashanker M, Shruti S. Traditional Indian herbal medicine used as antipyretic, antiulcer, anti-diabetic and anticancer: a review. IJRPC 2011; 1: 1152-9.

4. Passa P. Diabetes trends in Europe. Diabetes Metab Res Rev 2002; 18: 3-8.

5. International Diabetes Federation. The global burden. In: IDF Diabetes Atlas. $5^{\text {th }}$ ed. Brussels: IDF; 2011: 23-44 [cited 2013]. Available from: http://www.idf.org/diabetesatlas/5e/ the-global-burden.

6. Khuwaja AK, Fatmi Z, Soomro WB, Khuwaja NK. Risk factors for cardiovascular disease in school children - a pilot study. J Pak Med Assoc 2003; 53: 396-400.

7. Dichtwald S, Weinbroum AA, Sorkine P, Ekstein MP, Dahan E. Metformin-associated lactic acidosis following acute kidney injury. Efficacious treatment with continuous renal replacement therapy. Diabet Med 2012; 29: 245-50.

8. Joseph B, Jini D. Insight into the hypoglycemic effect of traditional Indian herbs used in the treatment of diabetes mellitus. Res J Med Plant 2011; 5: 352-76.

9. Afsheen N, Khalil-Ur-Rahman, N Jahan. Attenuation of chemically induced diabetes in rabbits with herbal mixture (Citrullus colocynthis and Cicer arietinum). Pak Vet J 2013; 33: 41-4.

10. Pan GY, Huang ZJ, Wang GJ, Fawcett JP, Liu XD, Zhao XC et al. The antihyperglycaemic activity of berberine arisesfrom a decrease of glucose absorption. Planta Med 2003; 69: 632-6.

11. Uanhong L, Caili F, Yukui R, Guanghui H, Tongyi C. Effects of proteinbound polysaccharide isolated from pumpkin on insulin in diabetic rats. Plant Foods Human Nutr 2005; 60: 13-6.

12. Ng TB, Wong CM, Li WW, Yeung HW. Insulin-like molecules in Momordica charantia seeds. J Ethnopharmacol 1986; 15: 107-17.

13. Naziroglu M, Cay M. Protective role of intraperitoneally administered vitamin $\mathrm{E}$ and selenium on the antioxidative defense mechanisms in rats with diabetes induced by streptozotocin. Biol Trace Elem Res 2001; 79: 149-59.

14. Elgawish A, Glomb M, Friendlander M, Monnier VM. Involvement of hydrogen peroxide in collagen crosslinking by high glucose in vitro and in vivo. J Biol Chem 1999; 271: 12964-71.

15. Ammon HPT, Wahl MA. Pharmacology of Curcuma longa. Planta Med 1991; 57: 1-7.

16. Srinivasan K, Sambaiah K. Effect of spices on cholesterol-7ahydroxylase activity and on serum and hepatic cholesterol levels in the rat. Int J Vit Nutr Res 1991; 61: 364-9.

17. Arun N, Nalini N. Efficacy of turmeric on blood sugar and polyol pathway in diabetic albino rats. Plant Foods Human Nutr 2002; 57: 41-52.

18. Murugan P, Pari L. Influence of tetrahydrocurcumin on hepatic and renal functional markers and protein levels in experimental type 2 diabetic rats. Basic Clin Pharmacol Toxicol 2007; 101: 241-5.

19. Nishiyama T, Mae T, Kishida H, Tsukagawa M, Mimaki Y, Kuroda M et al. Curcuminoids and sesquiterpenoids in turmeric (Curcuma longa L.) suppress an increase in blood glucose level in Type 2 diabetic KK-Ay mice. J Agric Food Chem 2005; 53: 959-63.

20. Peeyush, KT, Gireesh G, Jobin M, Paulose CS. Neuroprotective role of curcumin in the cerebellum of streptozotocin-induced diabetic rats. Life Sci 2009; 85: 704-10.

21. Xavier S, Sadanandan J, George N, Paulose CS. $\beta 2$-adrenoceptor and insulin receptor expression in the skeletal muscle of streptozotocin induced diabetic rats: antagonism by vitamin D3 and curcumin. Euro J Pharmacol 2012; 687: 14-20.

22. Na LX, Zhang YL, Li Y, Liu LY, Li R, Kong T et al. Curcumin improves insulin resistance in skeletal muscle of rats. Nutr Metab Cardiovasc Dis 2011; 21: 526-33.

23. Patumraj SN, Wongeakin P, Sridulyakul A, Jariyapongskul N, Futrakul, Bunnag $\mathrm{S}$. Combined effects of curcumin and vitamin $\mathrm{C}$ to protect endothelial dysfunction in the iris tissue of STZ-induced diabetic rats. Clin Hemorheol Microcirc 2006; 35: 481-9.

24. Soetikno V, Watanabe K, Sari FR. Curcumin attenuates diabetic nephropathy by inhibiting PKC- $\alpha$ and PKC- $\beta 1$ activity in streptozotocininduced type I diabetic rats. Mol Nutr Food Res 2011; 55: 1655-65. 
25. Jain SK, Rains J, Croad J, Larson B, Jones K. Curcumin supplementation lowers TNF- $\alpha$, IL-6, IL-8, and MCP-1 secretion in high glucosetreated cultured monocytes and blood levels of TNF- $\alpha$, IL-6, MCP-1, glucose, and glycosylated hemoglobin in diabetic rats. Antioxid Redox Signal 2009; 11: 241-9.

26. El-Moselhy MA, Taye A, Sharkawi SS, El-Sisi SFI, Ahmed AF. The antihyperglycemic effect of curcumin in high fat diet fed rats. Food Chem Toxicol 2011; 49: 1129-40.

27. Chougala MB, Bhaskar JJ, Rajan MGR, Salimath PV. Effect of curcumin and quercetin on lysosomal enzyme activities in streptozotocin-induced diabetic rats. Clin Nutr 2012; 31: 749-55.

28. Gutierres VO, Pinheiro CM, Assis RP, Vendramini RC, Pepato MT, Brunetti IL. Curcumin-supplemented yoghurt improves physiological and biochemical markers of experimental diabetes. Br J Nut 2012; 108: 440-8.

29. Sidhu GS, Mani H, Gaddipati JP, Singh AK, Seth P, Banaudha KK et al. Curcumin enhances wound healing in streptozotocin induced diabetic rats and genetically diabetic mice. Wound Repair Regen 1999; 7: 362-74.

30. Khan S, Mirza KJ, Anwar F, Zainul Abdin M. Development of RAPD markers for authentication of Piper nigrum (L). Environ Int J Sci Tech 2010; 5: 47-56.

31. Panda S, Kar A. Piperine lowers the serum concentrations of thyroid hormones, glucose and hepatic $5 \mathrm{D}$ activity in adult male mice. Horm Metab Res 2003; 35: 523-6.

32. Manoharan S, Silvan S, Vasudevan K, Balakrishnan S. Antihyperglycemic and antilipidperoxidative effects of Piper longum (Linn.) dried fruits in alloxan induced diabetic rats. J Biol Sci 2007; 6: 161-8.

33. Atal S, Agrawal RP, Vyas S, Phadnis P, Rai N. Evaluation of the effect of piperine per se on blood glucose level in alloxan-induced diabetic mice. Acta Pol Pharm 2012; 69: 965-9.
34. Srinivasan MR, Satyanarayana MN. Effect of black pepper (Piper nigrum) and piperine on growth, blood constituents and organ weights in rats. Nutr Rep Int 1981; 23: 871-6.

35. Cho SY, Lee SH. Effect of black pepper on the composition of serum and liver in rat. Hanguk Yongyang Siklyong Hakhoechi 1983; 12: 21924.

36. Politeo O, Jukic M, Milos M. Chemical composition and antioxidant activity of essential oils of twelve spice plants. Croatica Chem Acta 2006; 79: $545-52$.

37. Vijayakumar RS, Surya D, Nalini N. Antioxidant efficacy of black pepper (Piper nigrum L.) and piperine in rats with high fat diet induced oxidative stress. Redox Rep 2004; 9: 105-10.

38. Nabi SA, Kasetti RB, Sirasanagandla S, Tilak TK, Kumar MVJ, Rao CA. Antidiabetic and antihyperlipidemic activity of Piper longum root aqueous extract in STZ induced diabetic rats. BMC Comp Alt Med 2013; 13: 37.

39. FAOStat. Statistical Databases. Rome: Food and Agriculture Organization; 2010 [cited 2010 Jun]. Available from: http://faostat.fao.org

40. Al-Farsi MA, Lee CY. Usage of date (Phoenix dactylifera L.) seeds in human health and animal feed. Nuts Seeds Health Dis Prev 2011; 447-52.

41. El Fouhil AF, Ahmed AM, Darwish HH. Hypoglycemic effect of an extract from date seeds on diabetic rats. Saudi Med J 2010; 31: 747-51.

42. El Fouhil AF, Ahmed AM, Atteya M, Mohamed RA, Moustafa AS, Darwish HH. An extract from date seeds stimulates endogenous insulin secretion in streptozotocin-induced type I diabetic rats. Func Foods Health Dis 2013; 3: 441-6.

43. El Fouhil AF, Ahmed AM, Darwish HH, Atteya M, Al-Roalle AH. An extract from date seeds having a hypoglycemic effect. Is it safe to use? Saudi Med J 2011; 32: 791-6.

44. Halaby MS, Farag MH, Gerges AH. Potential effect of date pits fortified bread on diabetic rats. Int J Nutr Food Sci 2014; 3: 49-59. 